
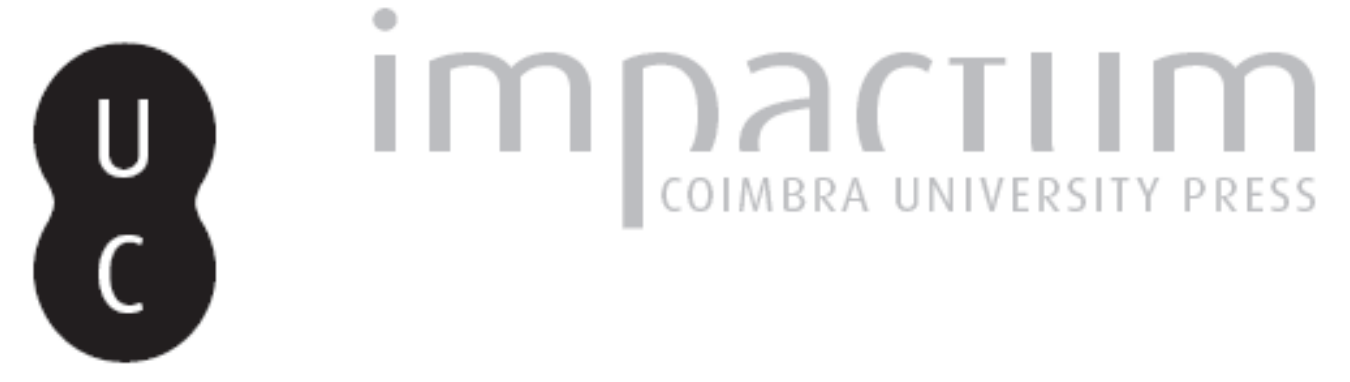

\title{
Corrupção e escândalo políto: o enquadramento dos escândalos Face oculta e Mensalấo na imprensa portuguesa e brasileira
}

Autor(es): $\quad$ Prior, Hélder; Guazine, Liziana; Araújo, Bruno

Publicado por: Imprensa da Universidade de Coimbra

URL persistente:

URI:http://hdl.handle.net/10316.2/36970

DOI:

DOI:http://dx.doi.org/10.14195/2183-5462_26_10

Accessed : $\quad$ 26-Apr-2023 13:58:43

A navegação consulta e descarregamento dos títulos inseridos nas Bibliotecas Digitais UC Digitalis, UC Pombalina e UC Impactum, pressupõem a aceitação plena e sem reservas dos Termos e Condições de Uso destas Bibliotecas Digitais, disponíveis em https://digitalis.uc.pt/pt-pt/termos.

Conforme exposto nos referidos Termos e Condições de Uso, o descarregamento de títulos de acesso restrito requer uma licença válida de autorização devendo o utilizador aceder ao(s) documento(s) a partir de um endereço de IP da instituição detentora da supramencionada licença.

Ao utilizador é apenas permitido o descarregamento para uso pessoal, pelo que o emprego do(s) título(s) descarregado(s) para outro fim, designadamente comercial, carece de autorização do respetivo autor ou editor da obra.

Na medida em que todas as obras da UC Digitalis se encontram protegidas pelo Código do Direito de Autor e Direitos Conexos e demais legislação aplicável, toda a cópia, parcial ou total, deste documento, nos casos em que é legalmente admitida, deverá conter ou fazer-se acompanhar por este aviso.

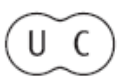




\section{Media Jornalismo}

\section{CORRUPÇÃO POLÍTICA, MEDIA E DEMOCRACIA}




\author{
CORRUPÇÃO E ESCÂNDALO POLÍTICO: O ENQUADRAMENTO \\ DOS ESCÂNDALOS FACE OCULTA E MENSALÃO NA \\ IMPRENSA PORTUGUESA E BRASILEIRA \\ CORRUPTION AND POLITICAL SCANDAL: THE FRAMEWORK \\ OF THE SCANDALS FACE OCULTA AND MENSALÃO IN THE \\ PORTUGUESE AND BRAZILIAN PRESS
}

\title{
HÉLDER PRIOR, LIZIANE GUAZINE E BRUNO ARAÚJO \\ POSCOM.@UNB.BR
}

\begin{abstract}
Resumo
0 artigo que 0 leitor tem entre mãos é uma tentativa de analisar a cobertura jornalística de dois escândalos de corrupção, o Face Oculta e o Mensalão, numa perspetiva comparativa. Versando, num primeiro momento, sobre os fenómenos da corrupção e do escândalo político, procuraremos analisar os conceitos à luz da FiIosofia Política, discorrendo sobre a sua relação sem, contudo, deixar de fazer a sua distinção analítica. Na parte empírica, adotaremos a teoria do enquadramento no sentido de compreender de que forma o semanário SOL (Portugal) e a Revista Veja (Brasil), operaram uma reconfiguração dos escândalos no momento da sua eclosão.

\author{
Palavras-chave \\ Corrupção, Escândalo, Enquadramento
}

\section{Abstract}

The essay that the reader is holding in his hands is an attempt to understand the news coverage of two corruption scandals, the Face Oculta and the Mensalão, as a comparative perspective. Let us discuss the corruption phenomena and this political scandal, we will analyze the concepts of political philosophy while discussing the relationship without bias the promotion of their distinct analytical views. In this empirical detail, we will adopt the news frame analysis in order to understand how the SOL (Portugal) and the Veja Magazine (Brazil) operated a mediated reconfiguration of these scandal at the moment of its disclosure.
\end{abstract}

\section{KeYWORDS}

Corruption, Scandal, News frame 


\section{CORRUPÇÃO E ESCÂNDALO POLÍTICO: 0 ENQUADRAMENTO DOS ESCÂNDALOS FACE OCULTA E MENSALÃO NA \\ IMPRENSA PORTUGUESA E BRASILEIRA \\ CORRUPTION AND POLITICAL SCANDAL: THE FRAMEWORK \\ OF THE SCANDALS FACE OCULTA AND MENSALÃO IN THE PORTUGUESE AND BRAZILIAN PRESS}

HÉLDER PRIOR, LIZIANE GUAZINA E BRUNO ARAÚJO | UNIVERSIDADE DE BRASÍLIA

POSCOM@UNB.BR

Corrupção, Escândalo e Poderes Ocultos

A existência de poderes ocultos no interior da esfera política não é, propriamente, uma ideia nova. Tampouco é uma ideia nova a desmistificação de círculos fechados no que se refere aos atos de governação. Durante a Idade Média, por exemplo, a esfera pública assumiu uma componente litúrgica característica das sociedades feudais. A visibilidade do campo político dependia quase exclusivamente da exaltação senhorial própria da relação entre suseranos e vassalos. De outro modo, sabemos que a esfera pública característica do Renascimento e do Barroco se pautou por uma publicidade representativa assente numa cultura aristocrática centrada na Corte (Habermas: 2006:46-47). A configuração da publicidade do poder não tinha que ver com a visibilidade dos atos do governo ou com a admissão do Terceiro Estado aos atos de deliberação. 0 poder apresenta-se perante os homens e não entre os homens que constituem o tecido societal (inter homines esse). Era de entendimento geral que os pequenos conselhos deliberavam melhor do que as grandes assembleias (Hobbes: 2002:165), e, portanto, à publicidade representativa corresponde uma técnica política conforme aos ideais de arcanum e de mysterium. Nos Estados autocráticos, o gabinete secreto, a sala secreta ou o conselho secreto, sempre foram o lugar privilegiado das deliberações políticas, e só a partir do século XVIII é que a política cerrada dos gabinetes deu lugar à ideia de publicidade e de visibilidade do poder (Schmitt: 2008:80-81).

Todavia, apesar do desenvolvimento do moderno Estado Constitucional, baseado nos ideais iluministas de "autoridade visível" e de transparência, a democracia e o constitucionalismo não aboliram, absolutamente, os redutos opacos e os poderes ocultos. A visibilidade erigiu-se como conditio sine qua non quer da política, quer do Direito ${ }^{1}$, mas tal não significa que ao lado do Estado visível, regido pelos princípios de publicidade e transparência, não se tenha constituído um Estado esotérico, pautado por redes obscuras de interesses parciais que se ocultam mediante novas formas de "poder invisível". 0 próprio Schmitt reconhece que a realidade da vida parlamentar e da ação dos partidos

1 Sobre o princípio da publicidade como conciliação entre moral, política e Direito vide Immanuel Kant, Que é o lluminismo?, 2004. 
políticos está muito distante da "fé na publicidade do poder" defendida pelos filósofos iluministas:

Comissões reduzidas de partidos ou de coligações de partidos decidem à porta fechada (...) os debates parlamentares não são mais do que uma formalidade vácua e fútil. O Parlamento, tal como se desenvolveu no século XIX, perdeu a base e o sentido que teve até agora (Schmitt: 2008:105-106).

Justamente neste ponto, o desvelamento destas formas ocultas do poder revela, muitas vezes, 0 desrespeito por procedimentos normativos que se configuram como esteio das democracias. Quando o mundo oculto da política se desvela perante os olhos do público, é provável que os procedimentos que regulam o exercício secreto do poder tenham sido transgredidos. Do ponto de vista que aqui nos interessa, a saber: a eclosão dos escândalos Face Oculta e Mensalão, cumpre observar a constituição do escândalo mediante a transgressão de procedimentos normativos evidenciada através da denúncia dos media. A transgressão de normas e de leis que regulam o exercício do poder constituiu-se, como John B. Thompson sublinha, como a "forma mais pura de escândalo político" (Thompson: 2000: 196). Numa altura em que as relações entre os cidadãos e as classes políticas se vêem afectadas por uma profunda crise de confiança, o desvelamento de poderes ocultos contribui para afectar 0 ethos da política e a credibilidade das suas instituições.

Se a Constituição descreve um Estado transparente onde a ação do governo se deve voltar para o interesse dos cidadãos, sabemos que parte da vida política se desenvolve no interior de um Estado obscuro e clandestino que muitas vezes dissolve 0 Estado de Direito. Uma vez conquistado o direito a exercer o poder político, a administração pública pode ser colonizada pelos interesses políticos assumidos, mas também pelos dirigentes partidários e respectivos grupos de interesse. Enquanto a vertente honesta desta colonização se orienta para a realização de uma política determinada que foi legitimamente sufragada pelos eleitores, a componente desonesta vem ao de cima quando os interesses pessoais ou particulares são perseguidos em detrimento dos interesses da comunidade.

Ora, quando a política como profissão se encontra ao serviço dos chamados beati possidentis, assegurando a viciação do sistema e a dominação das paixões e dos interesses parciais, a democracia como regnum da transparência deixa de cumprir a sua promessa. ${ }^{2}$ Nestes casos, 0 ato político transgride 0 Direito e a ética da profissão, sendo que a justiça como fundamento da governação, dá lugar à corrupção como consequência da governação. Entre as muitas definições sobre corrupção, há de se considerar que a corrupção do público começa quando o poder deixa de estar ao serviço do interesse geral para beneficiar os interesses particulares que se instalam na administração do Estado. Como muito sagazmente observa Alejandro Nieto, numa excelente obra dedicada ao Desgoverno do Público (2008), "a corrupção acompanha o poder como a sombra acompanha o corpo"

2 Para um autor como Norberto Bobbio entre as promessas não cumpridas pela democracia a mais irremediável, grave e destruidora é, precisamente, a da transparência do poder. Cf. Norberto Bobbio (2000). Teoria Geral da Política, a Filosofia Política e as Lições dos Clássicos. Rio de Janeiro: Elsevier Editora: 409. 
(Nieto:2008:154). Baltasar Garzón viu bem o intrincado deste problema ao observar que a corrupção política se traduz numa espécie de "privatização do Estado" onde aqueles que deveriam ser os "gestores" do Estado se convertem em "donos" dos serviços públicos (Brioschi: 2004:12). Por outro lado, de modo polémico, Baltasar Garzón reconhece que o desenvolvimento da história social e política é, também, 0 desenvolvimento da própria corrupção. Etimologicamente, corruptionis refere o que está podre ou decomposto, refere a decomposição da matéria orgânica. A partir do século XV, a palavra adquiriu o sentido que hoje se the reconhece sendo que, em português, há vestígios do uso da palavra "corruçom" durante o século XIV. ${ }^{3}$ Segundo o Dicionário da Língua Portuguesa Contemporânea, corrupção é sinónimo de "decomposição", de "putrefacção" ou "deterioração" dos valores morais, dos bons costumes. ${ }^{4}$ Quando transferido para a linguagem política, 0 ato de corrumpere refere a decomposição e perversão do exercício do poder nas tarefas públicas. Trata-se da perseguição de interesses "agradáveis" ou "vantajosos", nas palavras do Cardeal Richelieu, que, na maior parte das vezes, "são contrários aos interesses do Estado" (Richelieu: 2008: 266).

Todavia, e apesar das palavras corrupção e escândalo se associarem frequentemente, a relação entre os dois conceitos é meramente casual. Derivada da raiz "skand", que significa "surgir" ou "saltar", a palavra skándalon foi utilizada no Antigo Testamento Hebraico para se referir a "uma ocasião de tropeço", de "queda no erro". Tendo em conta o sentido herdado das escrituras sagradas, "escândalo" designa uma conduta pecaminosa, uma falha que pode conduzir à ruína. Porém, pertence a John Thompson o mérito de ter estabelecido uma definição mais precisa do conceito. Do ponto de vista sociológico, o escândalo refere-se, segundo o autor, "a ações ou acontecimentos que implicam certos tipos de transgressão, transgressão suficientemente séria para provocar uma resposta pública de reprovação ou indignação" (Thompson:2000:20). 0 mesmo é dizer que não há escândalo sem a transgressão de certos valores, e, por outro lado, sem a propagação da transgressão e sem a existência de um público que se sente ofendido pelo comportamento escandaloso e que, por isso mesmo, o publicita na esfera pública. Para que um acto corrupto dê lugar a um escândalo é fundamental que a transgressão se converta num elemento visível, isto é, se ofereça aos olhos do público. 0 escândalo apenas se constitui a partir do momento em que a transgressão se publicita, causando sentimentos generalizados de reprovação. Por outro lado, a corrupção existirá ainda que os atos que the deram origem se mantenham ocultos. Se a perversão de certos princípios mantiver o véu do segredo, ou, ainda que seja publicitada, se a perversão desses princípios não suscitar uma resposta pública de indignação, a "perversão" não dará lugar à eclosão de um escândalo.

Com efeito, é exactamente no momento em que denúncias de corrupção são divulgadas pelos meios de comunicação, tornando-se públicas, que se estabelece a possibilidade de constituição de um escândalo nos termos de Thompson. E,

3 Cf. José Pedro Machado (1995). Dicionário Etimológico da Língua Portuguesa. Segundo Volume. Lisboa: Livros Horizonte: 237.

4 Cf. Dicionário da Língua Portuguesa Contemporânea(2001). Primeiro Volume. Lisboa: Fundação Calouste Gulbenkian. Verbo: 994. 
se a problemática da corrupção tem assumido particular destaque na agenda pública, é em parte devido à forte mediatização de escândalos relacionados com a transgressão de normas que regem o exercício do poder político. Uma vez que a exposição pública é uma característica central dos escândalos, a sua existência depende de "meios institucionalizados de exposição" (Lowi:1988:9) que seleccionam, enquadram, moldam e configuram os acontecimentos que estiveram na origem daquilo a que Markovits e Silverstein apelidam de "violação do procedimento devido" (1988: 7).

A partir do momento que os media começam a explorar o acontecimento, as revelações que estão na base de um determinado escândalo mediático provocam um conjunto de novas revelações e explicações que adensam o debate público. Tal como refere Thompson: "uma revelação inicial que se visse seguida por um completo silêncio nunca se converteria num escândalo" (2000:157). Deste modo, os media operam como "um dispositivo" que concentra a atenção do público num determinado tema ou assunto, oferecendo, ao mesmo tempo, "uma abstração seletiva intencionalmente coerente" (Tuchman: 2002: 92) que confere ao escândalo a sua existência enquanto acontecimento público. À medida que se desenvolve nos media, a estória adquire novos contornos e novas significações, sobretudo porque os jornalistas procurarão obter novos dados que aumentem a complexidade da trama urdida e que atribuam novidade a uma intriga mediática que rapidamente se propaga na esfera pública. Ao enquadrarem os acontecimentos, os jornalistas seleccionam determinados recortes ou fragmentos da realidade que funcionam como esquemas de processamento das informações veiculadas e que, mediante propriedades específicas, estimulam perceções e compreensões do fenómeno. É por isso que, no processo de descrição de um acontecimento, "as notícias definem e moldam esse acontecimento", atribuído selectivamente aos acontecimentos públicos "um certo caráter" mediante o recorte de particularidades específicas. Como refere Tuchman, "os meios de comunicação são parte integrante do drama a estruturar", estando permanentemente a definir e a redefinir, a construir e a reconstruir os fenómenos sociais (Tuchman: 2000:93). Por estas razões, as nossas análises enfatizarão os momentos iniciais do que se constituiu como escândalo em Portugal e no Brasil, procurando identificar de que forma as publicações seleccionadas moldaram os acontecimentos.

\section{Questões Metodológicas}

Antes de iniciarmos a parte analítica, alguns apontamentos de ordem metodológica se fazem necessários. Primeiramente, é importante sublinhar a dimensão comparativa da análise sobre o desempenho de dois títulos da imprensa de referência, a revista Veja (Brasil) e o semanário SOL (Portugal), em face de dois grandes escândalos de corrupção surgidos na última década. Tal perspetiva de trabalho associa-se aos propósitos de Hallin e Mancini (2004), para quem a compreensão efectiva do papel dos media nas sociedades contemporâneas se dá através da comparação das suas várias actuações nos diversos espaços públicos. Para compreendermos o surgimento dos escândalos do Mensalão, na imprensa brasileira, e Face Oculta, na portuguesa, e a performance jornalística em relação à cobertura, recorreremos ao 
conceito-método ${ }^{5}$ de enquadramento. Inspirado na sociologia de Goffman - para quem os enquadramentos (frames) são "princípios de organização que governam os acontecimentos e o nosso envolvimento subjectivo neles" (Goffman: 1986:10-11) ,- 0 enquadramento tem vindo a ser utilizado em várias disciplinas, caraterizado pela grande transversalidade com que é mobilizado na investigação das ciências sociais e humanas. É comum observar o recurso ao enquadramento em análises de coberturas jornalísticas, mas também em estudos sobre audiência, organizações de media ou, ainda, no estudo de diferentes manifestações culturais. Nesse sentido, veja-se a cultura política brasileira - cujo entendimento é condição sine qua non para compreendermos o jornalismo em seu exercício diário - constituída por diversos valores e ideias que integram o imaginário popular ${ }^{6}$. Esses valores, socialmente partilhados, fornecem quer aos jornalistas, quer aos cidadãos em geral, modelos mentais que definem o modo como enxergamos a política e os políticos e nos relacionamos com eles. ${ }^{7}$ Apesar do esforço de vários autores para definir enquadramento, coube a Entman (1993) uma sistematização do conceito que permite entender as lógicas inerentes ao processo de enquadrar os acontecimentos da vida social e política. Diz o autor:

Enquadrar é seleccionar certos aspetos da realidade percebida e torna-los mais salientes no texto da comunicação de tal forma a promover a definição particular de um problema, de uma interpretação causal, de uma avaliação moral, e/ou a recomendação de tratamento para o tema descrito. Enquadramentos, tipicamente, diagnosticam, avaliam e prescrevem (Entman: 1993:53).

Por outro lado, Gitlin já havia conceituado enquadramento como "padrões pré-existentes de cognição, interpretação e apresentação, de seleção, ênfase e exclusão pelos quais os comunicadores (simbol handlers) organizam rotineiramente o discurso, seja ele verbal ou visual" (Gitlin: 1980:7). Para a análise do discurso de imprensa, que é o que nos interessa neste trabalho, é fundamental destacar as ideias de seleção, de saliência e de omissão de aspetos da realidade, a que tanto Gitlin (1980) quanto Entman (1993) fazem referência. Em diálogo com Tuchman (1978), podemos dizer que os enquadramentos funcionam como marcadores discursivos que dão uma linha orientadora às notícias. Explicamo-nos: ao enfatizar um determinado aspeto

5 Referimo-nos ao enquadramento como conceito-método porque ele funciona, ao mesmo tempo, como conceito, por trás do qual está uma reflexão que encontra na cultura o seu principal ponto de ancoragem, e como método de análise, de que é exemplo este e outros trabalhos desenvolvidos no campo da comunicação e das ciências sociais, de modo mais amplo.

6 A definição de cultura política de Moisés (2008) é uma das mais conhecidas no terreno da ciência política brasileira. Para o autor, os brasileiros compartilham valores em relação à política, que vão do clientelismo ao autoritarismo e à desconfiança na prática política e nos seus protagonistas, os políticos.

7 Em íntima relação com esse pensamento está o conceito de "enquadramento lúdico-dramático", de Motta (2010), muito próprio do jornalismo político. A partir das reflexões de Entman (1993; 2004), 0 autor defende que os enquadramentos devem ser vistos como algo ínsito ao próprio processo de reportagem. Desse modo, os jornalistas apropriam-se de quadros simbólicos, de enquadramentos socialmente partilhados, através dos quais tornam o mundo inteligível para o público. Em outras palavras, e recorrendo ainda a Motta, os jornalistas põem o mundo em perspetiva. 
da realidade representada, e ao secundarizar ou omitir outros, o jornalista aponta caminhos interpretativos dos acontecimentos, que serão ou não seguidos conforme as caraterísticas pessoais de quem os recebe. Com efeito, na esteira da perspetiva construcionista, subjacente aos estudos de enquadramento, o jornalista terá sempre de fazer escolhas e avaliações diante da matéria-prima bruta dos acontecimentos, a informação, cujo gigantesco número o obriga a definir estratégias para colocar ordem no caos da vida quotidiana.

Nesse sentido, a divisão do trabalho em editorias, a partilha de critérios de noticiabilidade, as linhas editoriais dos meios de comunicação, o uso da linguagem, os modelos textuais impostos por cada género textual e os próprios valores de quem conta a narrativa do mundo, são elementos integrantes da cadeia organizativa do trabalho jornalístico que influenciam na criação dos enquadramentos, especialmente daqueles que constituem a cobertura da realidade política de um país, como pretende elucidar a nossa análise. 0 funcionamento contínuo desses elementos, que se complementam, no dia a dia do profissional, deixa antever que os eventos são construídos, na medida em que resultam de um conjunto de escolhas do sujeito da enunciação, o jornalista, materializadas em signos de natureza linguística e translinguística que configuram o discurso do jornalismo.

Baseados nas reflexões de Tuchman (1978), Gitlin (1980) e Entman (1993; 2004), a análise que desenvolveremos em seguida visa identificar as linhas de interpretação que direcionam as matérias jornalísticas publicadas. Interessa observar, também, os valores mobilizados pelas publicações, bem como o modo como os atores sociais são posicionados, e a quem o enunciador impõe responsabilidades. Para isso, a análise dos corpora será realizada com base em três categorias, construídas a partir do trabalho de Entman (1993; 2004).

\section{Quadro 1 - Categorias de Análise}

\begin{tabular}{|c|l|}
\hline CATEGORIA & \multicolumn{1}{|c|}{ DESCRIÇÃO/MODO DE APLICAÇÃo } \\
\hline Ideia Organizadora & $\begin{array}{l}\text { Expressa o lugar que a informação o ocupada na estrutura do jor- } \\
\text { nal. Os elementos mais importantes para nossa análise foram: } \\
\text { a) as manchetes e b) os primeiros parágrafos, que podem indicar } \\
\text { pistas sobre a lógica sob a qual a notícia foi organizada. }\end{array}$ \\
\hline $\begin{array}{c}\text { Atribuição de Responsabilidade e } \\
\text { Julgamento Moral }\end{array}$ & $\begin{array}{l}\text { Observa-se a) o conteúdo propriamente dito, em especial as } \\
\text { palavras-chave, os verbos, adjetivos ou relações de causalidade } \\
\text { e consequência entre frases, e b) as ênfases. }\end{array}$ \\
\hline Indicação de "Solução" & $\begin{array}{l}\text { Compreende os comentários dos jornalistas ou das fontes, } \\
\text { dando um "fechamento" de sentido à matéria. }\end{array}$ \\
\hline
\end{tabular}

Adaptado de Guazina (2011) 9

8 Essa ideia se associa à noção de superestrutura do texto noticioso, apontado por Teun van Dijk (2005), constituída sobretudo por títulos, subtítulos e o primeiro parágrafo (lead) das notícias.

9 Com base nas sugestões de Entman (1993), estas categorias foram construídas por Guazina (2011) e aplicadas em sua tese de doutoramento sobre a cobertura do Jornal Nacional, da TV Globo, do Escândalo do Mensalão no Brasil. 


\section{Caraterização dos Corpus}

Como já esclarecemos, analisaremos a cobertura jornalística da revista Veja em face do aparecimento das primeiras denúncias que culminariam na consolidação do escândalo do Mensalão e, nas mesmas circunstâncias, a cobertura do semanário SOL diante da eclosão do escândalo Face Oculta. Para a análise do primeiro caso, o corpus é constituído por sete edições, publicadas de 18 de maio de 2005 e 29 de junho de 2005. No que diz respeito ao segundo, analisaremos nove edições, publicadas de 6 de Novembro de 2009 a 12 Fevereiro de 2010, altura em que 0 caso ganha conotações políticas mais evidentes.

0 corpus foi construído com base num critério triplo: i) quanto ao aspeto temporal, situamo-nos nas primeiras semanas dos escândalos - quando esses ainda não se encontram totalmente configurados, de modo a perceber a evolução da cobertura e do próprio acontecimento; ii) seleção de edições em que houve um evidente destaque dos casos; iii) no interior dessas edições, seleção das matérias com claras referências a ambos. Como terreno de análise, estabelecemos as zonas de maior proeminência nos veículos e no texto jornalístico: demos preferência às capas de Veja e às primeiras páginas do semanário SOL e aos títulos, subtítulos e leads das matérias selecionadas. Ainda assim, recorremos ao conceito de recorte, trabalhado por Orlandi (1989), para analisar trechos do discurso dos meios que consideramos emblemáticos para atender aos objectivos da análise.

\section{0 escândalo Face Oculta: análise da cobertura do semanário SOL}

0 escândalo Face Oculta, surgiu inicialmente como um processo judicial "despido" das conotações políticas que o enquadramento jornalístico do caso e a sua politização Ihe haveriam de conferir. As alegações jurídicas recaiam na existência de uma associação criminosa que procurava obter, mediante uma "teia de influências", benefícios privados junto de empresas públicas. A justiça deu como provada a existência de uma associação criminosa de "rede tentacular" liderada pelo sucateiro Manuel Godinho que tinha como objectivo conseguir favorecimento para a sua empresa, a 02, em concursos públicos de levantamento e limpeza de resíduos industriais para grandes empresas públicas. 0 caso ganhou proporções públicas em outubro e novembro de 2009, sendo que em março de 2011 o juiz de instrução decidiu quais os arguidos que deveriam ir a julgamento: 34 pessoas e duas empresas, incluindo o ex-ministro do Partido Socialista, Armando Vara. 0 processo terminou em Setembro de 2014, com a condenação de todos os arguidos por crimes de corrupção, tráfico de influências e associação criminosa. Apesar dos acontecimentos assim descritos parecerem relativamente lineares, a verdade é que este escândalo se converteu numa narrativa política com "uma certa veia romancista", como reconheceu o próprio Armando Vara ${ }^{10}$.

Desde a primeira edição sobre o escândalo que o então primeiro-ministro José Sócrates assume o papel de protagonista da intriga (especialmente com as revelações sobre escutas telefónicas entre Armando Vara e José Sócrates), e em algumas edições essa centralidade torna-se mais explícita. Na edição de 6/11/2009, 0 semanário posiciona José Sócrates como protagonista do escândalo com a man-

10 Declaração de Armando Vara à saída do Tribunal de Aveiro no dia 11 de novembro de 2011. 
chete: "Sócrates escutado em conversas com Vara". Ainda na primeira página, 0 jornal refere que das escutas efectuadas a Armando Vara, surgem conversas com José Sócrates onde "um dos assuntos tratados entre o primeiro-ministro e Vara foi o negócio da TVI". A informação de que José Sócrates foi intercetado nas escutas a Armando Vara ganha destaque em relação ao que seria apenas um escândalo financeiro. A notícia da página quatro da mesma edição refere que das conversas interceptadas "surgiram novos indícios" que se encontrariam a ser analisados por Pinto Monteiro, Procurador-Geral da República (PGR), sendo deixado em aberto que tais indícios estariam relacionados com o negócio PT/TVI e com "tráfico de influências". No corpo da notícia, é referido que "uma análise ao currículo dos arguidos permite concluir que o Face Oculta atingiu em cheio o PS e o círculo mais próximo de José Sócrates", algo que é ilustrado com um enquadramento lúdico em forma de teia sob o título: "a teia de influências do Face Oculta" (Sol, p. 4). Neste ponto, assistimos à personalização do acontecimento através da metáfora da teia, um frame que permite identificar as personagens do escândalo como "transgressores". Como o escândalo político tem, necessariamente, as suas dramatis personae, os indivíduos que estão no epicentro do escândalo, os envolvidos são colocados em relação tendo em conta o "papel" desempenhado na narrativa. Armando Vara, José Penedos, então presidente da REN (Redes Energéticas Nacionais), e Manuel Godinho são as personagens do fio condutor da notícia, mas sempre como elementos pertencentes ao círculo de Sócrates. É a metáfora da teia que ajuda a contextualizar a acção das personagens. Na imagem, é possível ver como as personagens realizam determinadas funções, uma vez que a linguagem visual oferece ao leitor a capacidade de atribuir significados através da intuição ou contextualização. As figuras da imagem, que a semiologia denomina de actantes, participam no processo narrativo através da uma hierarquia construída pelo jornalista. É mediante esta hierarquia que as suas funções na trama são descritas. Trata-se de uma espécie de enquadramento de compreensão (framework of understanding) que orienta não apenas a interpretação da ação dos actantes por parte do leitor, mas também a realização das ações dos actantes na narrativa do escândalo. Apesar de José Sócrates não estar indiciado de quaisquer crimes, é identificado como se fosse o "actante dominante" no processo de relacionamento que se estabelece entre todos os actantes. Já na peça seguinte onde se referem "as provas contra Vara e Penedos", o tom condenatório é evidente: "Vara apresentou gestores e Penedos favoreceu Godinho" (Sol, p. 6).

Porém, é a partir da edição de 13/11/2009 que 0 acontecimento se desdobra. Com o destaque, na manchete, que "Sócrates mentiu ao Parlamento sobre a TVI", 0 escândalo adquire uma nova configuração assente nas "transgressões de segunda ordem". Cruzando o teor das escutas filtradas pelo jornal com declarações públicas de Sócrates de 24/6/2009 - recurso ao flashback-, o jornal conclui que "José Sócrates mentiu ao Parlamento sobre a TVI". A narrativa mediática passou a ser costurada sobre o prisma da mentira parlamentar, tendo sido utilizadas expressões como "escutas provam conhecimento do negócio", ou "o primeiro-ministro faltou deliberadamente à verdade". Efetivamente, um dos episódios mais interessantes do escândalo Face Oculta refere-se à hipotética mentira parlamentar do então chefe do Governo. No dia 24 de Junho, José Sócrates, ao ser confrontado no debate quinzenal no Parlamento com o negócio PT/TVI, declarou que "o Governo não dá 
orientações, nem recebeu qualquer tipo de informação sobre negócios que tenham em conta as perspetivas estratégias da PT". Questionado pelos partidos da oposição, que demonstraram a sua preocupação face à possível intromissão do Estado na linha editorial da estação televisiva, José Sócrates reiterou que nem ele nem 0 Estado foram informados sobre o interesse da PT na TVI. Na sequência destas novas revelações, a edição de 13 de novembro recorre ao enquadramento temporal e cronológico para legitimar a sua fala e produzir efeitos nos leitores, reconstruindo os momentos mais significativos da história (p. 5). É a experiência do tempo, o frame temporal, que ordena os antecedentes, recria o passado e permite a significação tendo, naturalmente, em conta o interesse comunicativo da notícia. 0 frame temporal permite, de certa forma, comprovar a manchete: "Sócrates mentiu no Parlamento".

Nas edições seguintes, o caso das escutas continua a ser enfatizado pelo semanário, mas uma vez que não são noticiadas novas denúncias, a cobertura é menos exaustiva. Ainda assim, a narrativa continua a ser tecida em função da personagem José Sócrates. As edições de 27/11/2009 e 4/12/2009 são tecidas em função de "fugas de informação" para os arguidos, referindo que um dia depois do primeiro-ministro ter dito no Parlamento desconhecer o negocio PT/TVI, "vários suspeitos trocaram de telemóvel" (p. 6). Já a edição de 4 de Dezembro, fala de "uma estranha coincidência de troca de telemóveis", e José Sócrates é colocado novamente em relação com os arguidos mediante o frame verbal: "José Sócrates também mudou de telefone na mesma altura em que os arguidos do Face Oculta" (p. 15).

Como facilmente se constata, o momento da denúncia ocupou mais espaço informativo que o posterior desenvolvimento do assunto, tanto que as manchetes de 11/12/2009 e 18/12/2009 não contêm referências ao Face Oculta. Quanto às quatro edições do mês de Janeiro, apenas a edição de 8/01/2010 aborda 0 caso das escutas, mas sem revelar novas denúncias sobre o escândalo. 0 clímax dos escândalos é sempre acompanhado de mais matérias sobre o acontecimento e, caso não surjam novas denúncias, o escândalo vai perdendo visibilidade. Porém, é possível concluir que no momento da "revelação" ou "divulgação" do escândalo prevaleceu o tom de denúncia ou acusação, sendo que o jornal concentrou a sua cobertura nas "transgressões de segunda ordem".

Porém, durante o mês de fevereiro o caso haveria de conhecer novos contornos com a publicitação do conteúdo das escutas entre Armando Vara e José Sócrates. Novas denúncias são acrescentadas à estória e 0 escândalo financeiro converte-se, definitivamente, num escândalo político que haveria de levar à abertura de uma Comissão Parlamentar de Inquérito. É o período que podemos denominar de "crise política". 0 desdobramento do caso levou à revelação de novas denúncias desveladas mediante um trabalho de investigação jornalística e o recurso a fontes oficiais, como o despacho dos investigadores do Face Oculta onde estes defenderam a abertura de um inquérito por terem descoberto indícios relacionados com "transgressões de segunda ordem". 0 enquadramento das novas denúncias nas edições de 5/02/2010 e de 12/02/2010 passa pelo recurso às fontes e pelo papel que o campo do jornalismo lhes confere. A manchete intitulada "As escutas proibidas" revela um extracto do despacho do juiz que acrescenta novas filtrações ao escândalo. No interior do jornal, o despacho do procurador é revelado na íntegra. A edição de 5/02/2010 fala do "plano de Sócrates para controlar a TVI e outros media" (p. 4), referindo, 
em seguida, que este plano ou "esquema" configuraria crime de atentado contra o Estado de Direito, já que o governo estaria a subverter o Estado Constitucional e a colocar em causa a Liberdade de Imprensa. Através de extratos de escutas filtradas, e através de fontes oficiais, o jornal configura os acontecimentos numa nova narrativa, mais complexa, com novos episódios, novos momentos dramáticos e novas personagens. Denota-se uma relação recíproca entre a narratividade e a temporalidade dos acontecimentos. Esta experiência do tempo da intriga que, de certa forma, representa a ação, torna-a presente na mente do público, é reforçada, por exemplo, pelas seguintes expressões temporais: "no dia seguinte", "daí a dois dias", "estava-se a 19 de Junho", "nesse mesmo dia", ou "aos primeiros minutos do dia 24" (p. 7-8). A experiência do tempo permite que a narrativa adquira uma certa unidade, mormente porque possibilita organizar episódios complexos numa sequência que enforma a própria significação do fenómeno. Podemos dizer que da sequenciação de fragmentos singulares resulta uma conexão interna entre os diversos extratos que é essencial para a reconfiguração mediática do acontecimento. E, ao ser narrado, 0 acontecimento é representado para ser apreendido pelo leitor.

Por outro lado, em alguns momentos é visível que a organização da intriga acontece através da identificação e descrição das personagens envolvidas. Porém, é igualmente visível que a descrição procura pôr em evidência a relação existente entre as várias personagens, isto é, cada personagem é descrita tendo em conta as relações que estabelece ou estabeleceu com as outras personagens. E, naturalmente, esta construção tem consequências na reconfiguração que o próprio leitor fará dos acontecimentos. Rui Pedro Soares ${ }^{11}$, por exemplo, é caracterizado como um boy "socrático"12, como alguém que teve uma subida "meteórica" devido à confiança de José Sócrates. Posteriormente, é notório o recurso ao flashback para explicar a "surpreendente" entrada de Rui Pedro Soares na PT. Uma entrada que, segundo a narração jornalística, surpreendeu os "especialistas e quadros superiores" da própria empresa. Ao longo do texto, é explicado como este "socrático" entrou no inner circle do PS e como, posteriormente, se impõe na empresa de telecomunicações apesar de sua "falta de curriculum". No final do texto, é referido mais um pormenor interessante de construção jornalística. Rui Pedro Soares é identificado como sendo o responsável pelo apoio da PT ao clube de futebol Boavista, "clube condenado por corrupção desportiva pela Liga de Clubes", estabelecendo-se um nexo causal que não existe, mas que visa ter determinadas conotações $(5 / 02 / 2010$, p. 9).

0 rosto dos envolvidos é colocado não só em destaque (p. 7), mas, também, em relação, facto que permite que o público assimile as personagens e lhes atribua, na sua relação com os factos narrados, um determinado caráter, consciente ou inconscientemente. 0 frame visual é acompanhado pela legenda: "os pivôs do esquema". Através da personalização do enredo, os atores tornam-se visíveis para o leitor.

11 Nomeado pelo executivo de José Sócrates para o cargo de administrador na PT, Rui Pedro Soares era o homem de confiança do governo socialista na empresa de telecomunicações.

12 A narrativa dos boys já tinha sido abordada na edição de 20/11/2009. No editorial, José António Saraiva escreve sobre "Os boys de Guterres" e estabelece uma relação causal entre o Face Oculta e o "deslumbramento" dos boys Armanda Vara e José Sócrates que, oriundos da província, se mudaram para a "grande cidade" e se deixaram corromper pelo poder. 
Como, no caso específico do escândalo mediático, nos referimos a acontecimentos que, ao deixarem de estar confinados à esfera do segredo se difundem no âmbito público, acontecimentos que envolvem a transgressão de determinados preceitos, os protagonistas são rapidamente identificados como "transgressores", como os "pivôs de um esquema" que visava subverter princípios basilares do Estado de Direito. Na edição de 12/02/2011, a centralidade de José Sócrates torna-se ainda mais explícita. A manchete metafórica "o polvo" pretende significar que Sócrates e o os seus boys envolvidos no "esquema" agiram de forma similar ao polvo, construindo uma "rede de tentacular" que visava o controlo dos meios de comunicação. Trata-se de um enquadramento lúdico que desperta efeitos poéticos, que ornamenta a "realidade seletiva" e ajuda a despertar efeitos de sentido. Por outro lado, é visível uma certa intertextualidade entre a metáfora do polvo e a metáfora da "rede tentacular" da edição de 6/11/2009, sendo que, uma vez mais, Sócrates surge como aquilo que designámos anteriormente por actante dominante.

\section{O Mensalão: Análise da cobertura de Veja}

A análise da cobertura jornalística da revista Veja, uma das mais conhecidas publicações brasileiras, teve como fio condutor observar não somente as categorias de análise definidas na metodologia, mas também as indicações mais subtis de mudanças de linguagem e as significativas formas de nomear os principais atores das matérias e os acontecimentos narrados.

0 período analisado para este artigo compreendeu o estágio inicial de pré-cobertura do chamado Escândalo do Mensalão, indo desde a edição 1905 (de 18/05/2005) em que foi publicada a denúncia de corrupção na Empresa de Correios e Telégrafos, mais conhecida como Correios, uma das maiores e mais antigas empresas públicas brasileiras, fundada em 1663' ${ }^{13}$, até a edição 1911 (de 29/06/2005), onde já se estabelece e se reafirma quem são os principais culpados da crise ${ }^{14}$. É apenas na edição 1909, de 15/06/2005, que se menciona, pela primeira vez, o termo "mensalão" para se identificar a denúncia feita pelo então deputado federal Roberto Jefferson, do Partido Trabalhista Brasileiro - PTB, de pagamento de propina para parlamentares votarem a favor de projectos do governo Lula. Porém, a palavra ainda não ganha destaque nos textos nem a crise é caracterizada ainda como um "escândalo".

No total, foram analisadas 27 matérias sobre corrupção (entre reportagens e textos-resumo intitulados "guias" ou "dicionários", cujo objetivo era orientar/normatizar as interpretações dos acontecimentos narrados) de sete diferentes edições de Veja. Desta amostra, apenas a primeira edição não dedicou capa ao tema da corrupção. Destacaremos aqui as análises relativas às matérias de capa e os exemplos que mais se destacaram na observação de enquadramento.

Do ponto de vista de estrutura, as matérias publicadas na Veja seguem um padrão de editorialização dos conteúdos noticiosos bastante conhecido dos leitores brasileiros. Em geral, logo no início (no título, no destaque ou na abertura da matéria) a revista deixa claro seu posicionamento frente aos acontecimentos. Além disso, cos-

13 Cf. http://www.correios.com.br/sobre-correios/a-empresa

14 Obviamente a cobertura sobre o escândalo Mensalão não se esgota na última edição seleccionada. Porém, a nossa amostra está delimitada aos acontecimentos iniciais. 
tuma permear a narrativas com adjectivos, muitas vezes hiperbólicos; com frases que tentam vincular determinadas causas a consequências específicas, e com citações que corroboram (ou pretendem corroborar) o raciocínio lógico-especulativo defendido pelos autores. Importante registar que a revista também costuma dedicar algum espaço ao histórico anterior de personagens ou acontecimentos, a fim de retomar os novos factos dentro da organização lógico-temporal própria de suas narrativas.

Por outro lado, também utiliza, por vezes, fontes não identificadas para referendar as informações, assim como, ao contrário, costuma identificar explicitamente quem seriam os "culpados" ou "responsáveis" e indicar as possíveis soluções para os problemas da corrupção no país, do governo ou mesmo para os principais problemas do então presidente da República, Luiz Inácio Lula da Silva ${ }^{15}$. Interessante também observar que, de modo geral, os autores das matérias também explicitam sua aprovação ou desaprovação em relação às acções dos principais personagens e/ou acontecimentos.

As matérias de Veja também se caracterizam, de modo geral, pela utilização do conflito como categoria estruturante das narrativas quando posiciona personagens uns contra os outros, projectando sequências lógico-temporais e concatenando enredos mais ou menos completos ao longo das edições (Motta \& Guazina: 2010). Como afirmam os autores, o conflito não é uma categoria inerente do jornalismo, pois advém do campo da política, porém, funciona como um enquadramento cognitivo que estrutura acontecimentos, muitas vezes isolados, em histórias compreensíveis (p. 137). Neste caso, aliás, há de se considerar o papel que as matérias identificadas como "guias" (intitulada "Perus e cafunés", na edição 1907 do dia 01/06/2005) ou "dicionários" (intitulada "Dicionário da Crise", na edição 1911, de 27/06/2005) desempenham ao auxiliarem na organização interpretativa dos conteúdos noticiosos, reafirmando e/ou esclarecendo os parâmetros de compreensão preferencial oferecidos pela revista sobre os acontecimentos.

Ao se observar o conjunto das matérias, é possível traçar, em linhas gerais, 0 roteiro de cobertura de Veja no período seleccionado. Na primeira edição analisada, ainda em Maio, apenas uma matéria se dedica à denúncia de corrupção nos Correios, quando o então funcionário Maurício Marinho é flagrado em gravação de vídeo ao receber $R \$ 3$ mil reais de propina de empresários. Na gravação, ele discorre sobre sua relação com o Partido Trabalhista Brasileiro - PTB e com então presidente do partido, deputado federal Roberto Jefferson (que, mais tarde, denunciará o chamado "mensalão").

Sob o título "O homem-chave do PTB", a matéria anuncia, em destaque sobre a foto, antes do parágrafo de abertura, que "o caso que se vai ler e ver (e ouvir em www.veja.com.br) é um microcosmo da corrupção no Brasil. Dá arrepios pensar que a mesma coisa está ocorrendo agora em milhares de outras repartições, prefeituras, câmaras municipais...". A matéria segue destacando uma cena que seria recorrente na política nacional de "políticos disputando, com unhas e dentes, a ocupação de cargos em todos os níveis de governo, da Esplanada dos Ministérios às Câmaras

15 Estes procedimentos, não custa lembrar, não encontram guarida na literatura académica sobre as práticas jornalísticas, inclusive do ponto de vista dos padrões liberais da profissão. No processo de apuração e redacção das notícias, a transparência no uso das fontes e o compromisso com a comprovação dos factos é essencial. Cf. Kovach e Rosenstiel (2003). 
Municipais. (...)". Ao longo do texto, é feito uma espécie de mapa discursivo dos cargos do PTB no governo e se descreve o histórico de casos de corrupção no partido.

É possível identificar, em trechos explícitos, a quem se atribui a origem da corrupção no governo Lula ou de quem é a culpa (os 25 mil cargos de confiança no governo, todos controlados pelo chefe da Casa Civil da Presidência da República, 0 então ministro José Dirceu), o julgamento moral da revista sobre o facto - que considera a corrupção como fenómeno geral nos governos, não casos isolados (como no trecho da p. 57: "quem tem intimidade com o poder sabe que esses casos não são exceção - alguns bolsões de corrupção são até mesmo a regra. Raro mesmo é flagrar um deles em pleno voo. Foi o que Veja conseguiu na semana passada.") e a indicação de solução do problema da corrupção, como na p. 60: "a forma mais eficaz de evitar que esse festival de irregularidades prossiga é reduzir o número de 25 mil cargos de preenchimento político - todos eles, um a um, controlados pelo Chefe da Casa Civil, o ministro José Dirceu".

Já a edição seguinte (1906, de 25/05/2005) dedica a capa e quatro matérias diferentes ao tema da corrupção. Na primeira matéria (intitulada "Diga-me com quem andas..."), a ênfase recai sobre a repercussão da denúncia sobre corrupção nos Correios e a organização, por parte de Roberto Jefferson, de uma rede de corrupção que teria deixado o Palácio do Planalto (sede da Presidência da República) "atônito". Ao longo da matéria, pode-se observar a atribuição de responsabilidade pela corrupção ao governo Lula (que, "como os anteriores, tem sua parcela de culpa pela situação atual"- p. 39). De acordo com a matéria, se o governo Lula tivesse se dedicado a fazer a reforma administrativa (diminuindo o número de cargos na estrutura de poder) e a reforma política, não seria necessário o Presidente Lula ter saído em defesa de Roberto Jefferson e ter actuado contra a instalação da Comissão Mista Parlamentar de Inquérito no Congresso Nacional, mais conhecida como $\mathrm{CPI}$ dos Correios. Tanto a reforma administrativa, quanto a reforma política e a instalação da CPI são defendidas no decorrer do texto.

Já a segunda matéria, intitulada "Mesada de 400 mil reais para o PTB", destaca que o governo tomou as providências necessárias depois da denúncia de corrupção nos Correios, mas enfatiza também que "tais providências, por mais eficazes que venham a se revelar, são tímidas para a dimensão do caso e, portanto, incapazes de atingir o cerne do problema"(p. 40). Para a revista, o "esquema" de corrupção do PTB estaria instalado não somente nos Correios, mas também nos demais órgãos da máquina pública, e o responsável pelo "esquema" seria o deputado Roberto Jefferson. Neste caso, é interessante observar o deslocamento do foco da denúncia e da culpabilização dos actores: passa de um caso nos Correios para um "esquema" que atinge todo o governo Lula. E se o próprio governo é culpado, pois não realiza reformas e impede as investigações, também o então deputado Jefferson é considerado "o grande protagonista do vídeo de corrupção dos Correios"(p. 41) e o responsável pelo "esquema" em outros órgãos públicos.

Na terceira matéria da mesma edição, intitulada "A maior crise de Lula", o destaque é dado à atuação do governo e do então presidente da República, Luiz Inácio Lula da Silva no caso. As ênfases começam já na chamada logo abaixo do título: "atingido por um estado de espírito que varia entre o irritado e o assustado, o governo - quanto ironia! - faz tudo contra a CPI" (p. 41). No decorrer do texto, observa- 
mos 0 tom de cobrança da revista em relação à postura do presidente e do governo de tentar evitar a instalação da CPI (ainda que integrantes do Partido dos TrabaIhadores, base do governo, tenham apoiado) e o enquadramento dado ao posicionamento dos diferentes actores políticos em termos de ataque/defesa. Em termos diretos em relação ao presidente, o texto afirma que "Lula deve uma explicação aos brasileiros sobre por que está antevendo crise política e perigo para as instituições na investigação de corrupção de um funcionário do terceiro escalão dos Correios ligado a caciques do PTB, partido que, não é de hoje, sempre esteve na coluna dos custos dos governantes"(p. 45) Já na quarta matéria, intitulada "Temporada de caça aos ratos", a ênfase é contextualizar o problema da corrupção na história brasileira, identificando as ações contra a corrupção como uma "guerra" do Brasil, não do Estado, da cidadania ou do governo. A noção de que a corrupção é um fenómeno generalizado, presente na primeira edição analisada, de 18/05/2005, volta a ocupar a centralidade do enquadramento da matéria. Além disso, há um tom "conformista" de que o país falha no combate a este tipo de problema (como na abertura: "Se 0 combate à corrupção fosse uma maratona, o Brasil seria um competidor medíocre, daqueles que ficam com a língua de fora antes da metade do percurso").

Ademais, ao mostrar dados e levantamento histórico sobre 0 combate e o custo da corrupção, a matéria também evidencia sua perceção sobre como lidar com a questão e sua defesa do que deve ser feito. No trecho a seguir, é possível observar o enquadramento dado: "Acabar completamente com a imoralidade pública é uma meta utópica. 0 que é possível fazer é conseguir chegar a um nível de corrupção que corresponda apenas à fraqueza inerente da condição humana - ou a um nível em que, como diz o ditado popular, a ocasião faz o ladrão. No Brasil de 2005 os ladrões do dinheiro público estão fazendo a ocasião. Isso pode e deve acabar" (p. 48).

A edição seguinte (1907), de 01/06/2005, dedica a capa ao "Homem-Bomba" Roberto Jefferson e destaca na matéria principal "0 que será que ele sabe?" o papel de Jefferson nas denúncias de corrupção, além do desenrolar das relações entre seu partido e o governo Lula. Também enfatiza, na abertura, o "tradicional arsenal" que estaria sendo utilizado pelo Palácio do Planalto contra a instalação da CPI dos Correios: "ameaças, cargos e dinheiro". Ao longo do texto, que utiliza fonte não explicitamente identificada, mas que se depreende poderia ser o próprio Jefferson, descreve-se os pedidos de integrantes do governo a Jefferson para impedir a CPI e as possíveis causas da aliança PTB-governo, além dos diferentes posicionamentos frente à CPI dentro do próprio PT, partido do governo.

De forma explícita, a revista identifica o "Planalto" como o principal responsável por alimentar o "regime de engorda do PTB, que saiu das urnas com 26 deputados e hoje tem 47 - crescimento que, como até as emas do Palácio da Alvorada sabem, não costuma se materializar à base de argumentos políticos ou ideológicos"(p. 50). Neste caso, há a ilação de que haveria troca de apoio partidário por dinheiro e que é esta a principal razão que levaria a casos de corrupção.

Outras três matérias, com diferentes focos de interesse relacionados à corrupção fazem parte da edição, mas destacaremos aqui o texto "Perus e cafunés", que é identificado como guia para interpretação/tradução das falas dos políticos envolvidos nas acusações (ou "um guia para decifrar a crise" - p.60). Logo na abertura há uma identificação entre Brasília, a capital do Brasil, e a prática das elites políticas, além 
do uso do recurso da comparação com um tipo de cinema e língua supostamente de difícil acesso: "Brasília parece filme iraniano. Sem legendas, fica difícil entender 0 que os políticos dizem"(p. 60). Interessante observar, na sequência deste exemplo, a definição de política presente no texto que enfatiza o caráter negativo do campo: "Até porque a política, em larga medida, é a arte de usar palavras para esconder intenções. No afã de desviarem de temas incômodos, integrantes do governo e da oposição vem abusando da máquina de moer bobagens imaginada pelo pensador americano Ralph Waldo Emerson, aquela em que se colocam lugares-comuns de um lado e de outro saem frases feitas. Tudo isso para evitar o único assunto que realmente interessa: quem está roubando, quanto e como (p. 60)".

Já a edição 1908, de 08/06/200516, dedica atenção especial novamente ao tema da corrupção, mas enfatiza outro caso relacionado à atuação de políticos do PT e agentes públicos na exploração económica na Amazónia (a capa destaca: "Amazônia à venda"). Nesta edição, que traz cinco diferentes matérias sobre o tema, destacaremos o texto intitulado "Lutar contra a corrupção já é uma vitória" (que, na verdade, é uma introdução que enquadra as perspetivas das demais matérias). Aqui, novamente a revista reforça a ideia, presente em outros textos e enfatizada no parágrafo de abertura, de que a corrupção "não pode ser vencida", mas que sua luta em criar "uma disposição moral, cultural e econômica" seria equivalente a "dar um enorme salto civilizatório, como o que o Ocidente deu muitos séculos antes do Oriente rumo à valorização da vida (...)"(p. 118). 0 argumento presente é de que mesmo que não se possa erradicar a corrupção, é possível combatê-la (como a Polícia Federal estaria a fazer).

Outro texto, tratado como reportagem e intitulado "Operação de guerra", enfatiza 0 que seria uma mudança de avaliação do presidente Lula em relação às denúncias de Jefferson. Se antes o presidente havia ficado indignado, agora estaria a evitar as investigações. Neste exemplo, também há uma retomada da atribuição de responsabilidade do governo, do presidente e do PT em relação à corrupção que estaria a tomar conta de todo o governo.

Já na edição 1909, de 15/06/2005, utiliza-se, pela primeira vez, o termo "mensalão", ainda que sem destaque, e o foco das matérias passa a ser o Partido dos Trabalhadores - PT. Seis matérias compõem a edição e, mais uma vez, os textos reforçam a ideia geral de que casos de corrupção são frequentes e tomaram conta de diferentes áreas de governo, não somente em âmbito federal, mas também estadual e municipal (como nas denúncias em relação à Marta Suplicy em sua gestão na prefeitura de São Paulo).

0 mais importante para nossa análise é que, nesta edição, há um deslocamento das atribuições de responsabilidade (culpabilização) e das causas da corrupção. Se antes tratava-se de uma denúncia em relação a corrupção nos Correios, passou-se para "esquemas" de corrupção que envolvia a entrega de cargos em órgãos públicos pelo governo a integrantes de partidos da base do próprio governo; com a consequente cobrança de propina por parte dos membros destes partidos em contratos de órgão públicos para financiamentos dos gastos partidários. Nesta sequência lógica,

16 Esta edição é posterior à entrevista de Roberto Jefferson ao jornal Folha de S. Paulo em que denuncia, pela primeira vez, a existência do que chamou de "mensalão". No entanto, é somente na edição seguinte, de 15/06/2005, que o mensalão se tornará foco das matérias de Veja. 
os principais culpados eram o próprio governo Lula, que não realizava reformas e evitava investigações, além do presidente e, em alguma medida, o então Chefe da Casa Civil, José Dirceu, responsável pela estratégia política do governo. Até então, a corrupção poderia ser definida como fenómeno endémico na estrutura governamental.

Após a denúncia de Roberto Jefferson ao jornal Folha de S. Paulo, a revista orienta o foco para o desenrolar da ação de novos atores e de novos factos. A capa da edição 1909 é uma foto de Delúbio Soares (então tesoureiro do PT) e a manchete: "Quem mais?". Na principal reportagem ("O PT assombra o Planalto"), há uma cobrança direta em relação ao PT e seu histórico de defesa da ética na política brasileira: "Alvejado pela acusação de comprar deputados com mesada de 30000 reais, o PT vê desmoronar seu discurso ético e enfrenta uma crise que, no seu desdobramento mais dramático, pode afundar o governo junto" (p. 53).

A matéria traz ainda um resumo das denúncias de Jefferson e um quadro com um histórico do caso. Para a revista, o principal responsável pela corrupção do Mensalão é o PT e, para corroborar a conclusão, utiliza citação do próprio presidente Lula: "(...) Lula acusou o governo o PT de estar acabando com o governo e exigiu que o partido afastasse 0 tesoureiro do cargo enquanto as investigações fossem realizadas. № dia seguinte, ao saber que não fora atendido, fez um desabafo: o PT não entendeu o tamanho da crise, disse" (p. 58). Lula passa, então, a ser a figura ao mesmo tempo acusada (a ex-senadora Heloisa Helena, do PT, o culpa pelo escândalo na matéria), e defendida (ele declara que vai cortar na própria carne). Também é a primeira vez que se menciona a possibilidade de impeachment do presidente no período analisado.

Já as demais matérias retomam os detalhes do caso dos Correios (em "0 que Jefferson omitiu"), exploram as repercussões dos escândalos de corrupção para a economia brasileira (em "Blindagem até quando")17, e denunciam e/ou retomam outros casos em diferentes instâncias do poder ("Mais um na mira", "0 mensalão da perua" e "0 PT deu a senha para desmatar", onde já se descreve o partido como uma "organização criminosa").

Em seu conjunto, as edições seguintes 1910 (de 22/06/2005) e 1911 (de 29/06/2005) aprofundam a atribuição de responsabilidade pelo Mensalão ao PT e, principalmente, a José Dirceu, que se torna figura-chave na cobertura dos acontecimentos. A capa da edição 1910 destaca a imagem de Lula como uma estátua em ruínas, mas a matéria principal ("Nocaute") narra a saída de Dirceu do cargo de Chefe da Casa Civil e enfatiza o papel dele no governo, atribuindo a ele e ao acordo PTB-PT, a principal culpa pela ocorrência do Mensalão. Se o PT era considerado o principal responsável, agora um de seus mais influentes membros passava a ser o foco das notícias ${ }^{18}$.

Após um histórico sobre o caso e sobre o papel de Dirceu na história política brasileira (como militante contra a ditadura e ex-exilado político), no partido e no governo, o texto é directo em atribuir a responsabilidade ao agora ex-Chefe da Casa Civil: " (...) José Dirceu assumiu seu posto como uma glória do governo, mas saiu de lá como sua tragédia. Foi ele quem levou para o regaço do governo legendas como PTB, PL e

17 Nesta matéria, há um infográfico dos escândalos e já se faz a diferença entre o caso de corrupção nos Correios (em maio) e o Mensalão (em junho).

18 No texto, explora-se o conflito entre Jefferson e Dirceu, em termos de protagonista e antagonista das ações, como já havia sido observado por Motta e Guazina (2010) na cobertura do Jornal Nacional, principal telejornal da Rede Globo de televisão. 
PP - e ao executar sua estratégia, produziu um duplo desastre: uma base parlamentar gelatinosa e o escândalo do mensalão" (p. 49). Interessante observar também a aprovação explícita da revista em relação à saída de Dirceu do governo devido à ação do presidente: "Com a saída de Dirceu, porém, Lula dá um passo fundamental em direcção a duas coisas essenciais: salvar seu governo e preservar sua biografia" (p. 50).

Já na última edição analisada, de 29/06/2005, a capa indica diretamente 0 que seria 0 erro do partido: "confundir o partido com o governo", reforçando, mais uma vez a atribuição de culpa ao PT. A principal matéria ("Muito barulho por nada"), por sua vez, dialoga diretamente com as principais estratégias de defesa do próprio partido e do governo durante o desenrolar dos acontecimentos até ali ao destacar seus contra-argumentos ao partido e a Dirceu: "Não há complô das elites, não há movimentos sociais que incendeiam o Brasil. Não há também José Dirceu o revolucionário, mas um fantasma de uma ideia que morreu".

\section{Considerações Finais}

Analisar comparativamente, em termos qualitativos, constitui-se sempre um desafio. Porém, apesar das dificuldades metodológicas e de contextualização dos fenómenos observados, é possível avançar em algumas considerações, ainda que limitadas à observação sistemática de uma amostra reduzida.

Ao compararmos a cobertura de denúncias de corrupção envolvendo figuras-chave dos governos português e brasileiro nas publicações de o semanário SOL e Veja, respectivamente, pudemos identificar como se configuraram os contornos iniciais do que ficou conhecido como os escândalos Face Oculta e Mensalão. A análise do enquadramento mediático operado pelo o semanário SOL entre novembro de 2009 e fevereiro de 2010, permite concluir que, de escândalo com caraterísticas vincadamente financeiras, segundo a tipologia de Thompson, o Face Oculta converteu-se num escândalo político com vários sub-escândalos, como a tentativa de compra da estação de televisão TVI pela Portugal Telecom (PT) ou a mentira do então primeiro-ministro, José Sócrates, no Parlamento. 0 Face Oculta mostra-nos que, muitas vezes, os escândalos são narrativas complexas onde da investigação das "transgressões de primeira ordem", das transgressões iniciais que estão na origem do escândalo, se descobrem novos indícios ou novas transgressões que podem alterar quer a tipologia do escândalo em causa, quer o enquadramento selectivo dos relatos informativos que, de acordo com Tuchman, confere às ocorrências a sua existência como acontecimentos públicos (2002: 97). Este segundo nível de transgressões, que Thompson define como "transgressões de segunda ordem", desempenhou um papel crucial na narrativa do escândalo, desviando a atenção que antes incidia sobre as transgressões iniciais para um conjunto de ações ulteriores e que guardam uma relação superficial com as transgressões de primeira ordem, como o caso das escutas telefónicas a Armando Vara e a José Sócrates no âmbito da investigação ao Face Oculta que revelaram uma tentativa de intromissão do Estado em órgãos de comunicação social.

Assim como no semanário SOL, o escândalo do Mensalão nasceu, de acordo com a narrativa analisada, a partir de uma denúncia secundária publicitada pela revista Veja, envolvendo um caso de corrupção ativado por um agente público de baixa hierarquia nos Correios brasileiros. No entanto, este caso alçou o tema da corrupção à centrali- 
dade da cobertura da revista, tornando-o presente em várias edições, e sempre a partir de uma caraterização de que seria um problema endémico ao governo brasileiro.

A partir da edição do dia 15 de junho, quando se menciona pela primeira vez 0 termo Mensalão, há um deslocamento nas atribuições de responsabilidade sobre a corrupção, que até então seria maioritariamente do governo, para o Partidos dos Trabalhadores e o então Chefe da Casa Civil, José Dirceu.

Interessante observar que o foco em figuras-chave dos governo brasileiro e português, como Dirceu e Sócrates, são características das narrativas observadas. Porém, se a ênfase na responsabilidade de Sócrates aparece logo no início da cobertura do semanário SOL, no caso de Veja a ênfase em atribuir a culpa em Dirceu só ganha força ao final do período analisado, quando a narrativa do escândalo já se configura mais organizada em termos lógico-temporais e os múltiplos sub-escândalos se tornam mais claros (a cobertura de Veja sobre o Mensalão estende-se ainda por muitas edições além das analisadas).

Ao final, há de se considerar também como 0 relato de ambos os escândalos são situados no tempo mediante uma extensão cronológica de desdobramento da ação em certos momentos. A temporalidade surge, assim, ligada à capacidade de organizar os acontecimentos fragmentados das edições anteriores e contar uma "estória" mais complexa. 0 "quando" e o "como" convertem-se em frames verbais constitutivos da narrativa do escândalo, especificamente porque permitem situar 0 leitor no tempo dos acontecimentos, ajudar o jornalista/narrador a organizar o tempo enunciativo e, por conseguinte, o próprio discurso jornalístico.

\section{BibliográfiA}

Bobbio, N. (2000). Teoria Geral da Política, a Filosofia Política e as Lições dos Clássicos. Rio de Janeiro: Elsevier Editora.

Bourdieu, P. (1997). Sobre a Televisão. Rio de Janeiro: Jorge Zahar Editor.

Brioschi, C.A. (2010). Breve Historia de la Corrupción, De la Antiguedad a nuestros días. Madrid: Taurus.

Cunha, I. F. e Serrano, E. (coords) (2014). Cobertura Jornalística da Corrupção Política: sistemas políticos, sistemas mediáticos, enquadramentos legais. Lisboa: Alêtheia.

Dicionário da Língua Portuguesa Contemporânea(2001). Primeiro Volume. Lisboa: Fundação Calouste Gulbenkian/ Verbo, 2001.

Dijk, T. V. (2005). Notícia, Ideologia e Poder. Estudos da Análise Crítica do Discurso. Porto: Campo das Letras.

Entman, R. (1993). Framing: Toward Clarification of a Fractured Paradigm. Journal of Communication 4: 51-58.

Entman, R. (2004). Projections of Power. Chicago: Chicago University Press.

Goffman, E. (1986). Frame analysis: an essay on the organization of experience. Boston: Northeastern University Press.

Guazina, L. S. (2011). Jornalismo em busca de credibilidade: a cobertura adversária do Jornal Nacional no Escândalo do Mensalão. Tese de doutoramento. Brasília: Universidade de Brasília. Habermas, J. (2006). Historia y crítica de la opinión pública; La transformación estructural de la vida pública. Barcelona: Gustavo Gili. 
Hall, S. (1980). Encoding and Decoding. In: Hall, S. et al, .Culture, Media, Language. London/Birmingham: Hutchinson/CCCS.

Hallin, D. \& Mancini, P. (2004). Comparing Media Systems. Three Models of Media and Politics. Cambridge: Cambridge University Press.

Hobbes, T. (2002). Do Cidadão. São Paulo: Martins Fontes.

Kant, I. (2004). Que é o lluminismo. In: A Paz Perpétua e Outros Opúsculos. Lisboa: Edições 70.

Kovach, B. \& Rosenstiel, T. (2003). Os elementos do jornalismo - O que os jornalistas devem saber e o público exigir. São Paulo: Geração Editorial.

Lowi, T. J. (1988). Prefácio. In: Markovits, A. S. \& Silverstein, M. (orgs). The Politics of Scandal: Power and Process in Liberal Democracies. New York: Holmes \& Meier Publishers.

Machado, J.P. (1995). Dicionário Etimológico da Língua Portuguesa. Segundo Volume. Lisboa: Livros Horizonte.

Markovits, A. S. \& Silverstein, M. (1988). Introduction: Power and Process in Liberal Democracies. In Markovits, A. S. \& Silverstein, M. (orgs). The Politics of Scandal: Power and Process in Liberal Democracies. New York: Holmes \& Meier Publishers.

Moisés, J. A. (2008). Cultura Política, Instituições e Democracia: lições da experiência brasileira. Revista Brasileira de Ciências Sociais - ANPOCS 66:11-43.

Motta, L. G. \& Guazina, L. (2010). 0 conflito como categoria estruturante da narrativa política: 0 caso do Jornal Nacional. Brazilian Journalism Research, vol. 6 (1) edição online (http://www.sbpjor.org.br/ojs/, 2010) (acedido 01/2015)

Motta, L. G. (2010). Enquadramentos lúdico-dramáticos no jornalismo: mapas culturais para enquadrar narrativamente os conflitos políticos. In: Miguel, L.F. \& Biroli, F. (eds.). Mídia: representação e democracia. São Paulo: Hucitech.

Nieto, A. (2008). El Desgobierno de lo público. Barcelona: Editorial Ariel.

Orlandi, E. P. (1989). Vozes e contrastes: Discurso na cidade e no Campo. São Paulo: Editora Cortez. Platão (1991). Apologia de Sócrates. Coimbra: Centro de Estudos Clássicos e Humanísticos da Universidade de Coimbra.

Prior, H. (2012). Esfera Pública e Escândalo: o secreto no âmbito público, Tese de Doutoramento. Covilhã: Universidade da Beira Interior.

Richelieu (2008). Testamento Político. Lisboa: Círculo de Leitores.

Schmitt, C. (2008). Los fundamentos histórico-espirituales del parlamentarismo en su situación actual. Madrid: Tecnos.

Thompson, J. B. (2000). Political Scandal, power and visibility in the media age. Cambridge: Polity Press. Tuchman, G. (1978). Making News: a study in the construction of reality. New York: The Free Press. Tuchman, G. (2002). As notícias como realidade construída. In: Esteves, J.P. (ed.). Comunicação e Sociedade. Lisboa: Livros Horizonte. 